\title{
NEO-COLONIALISM, POSTCOLONIALISM AND THE BANE OF NEO - ESSENTIALIST THEORISING IN CURRENT AFRICAN LITERATURE
}

DOI: http://dx.doi.org/10.4314/ft.v4i1.2

\author{
Idom T. INYABRI PhD \\ Department of English and Literary Studies, Faculty of Arts, University of Calabar
}

\begin{abstract}
This paper is a response to Joseph Ushie's argument for Neo-colonialism rather than Postcolonialism as the most appropriate theory for the criticism of what he calls Current African Literature. His proposition is based on the premise that Postcolonialism as a theory runs counter to the neo-colonial situation of Africa since the attainment of flag independence by different African nations. Hence, neocolonialism answers directly to the socio-political and economic condition of most African countries and should be utilised in the appreciation of most literatures from the continent. In this meta-criticism we proceed by making bare the crux of Ushie's argument, then identify obvious contradictions in his logic and critically present the merit of Postcolonialism as a cultural theory fit enough for the critical engagement of Current African Literature.
\end{abstract}

Keywords: Neo-colonialism, Postcolonialism, African Literature, Critical Theory, Meta-criticism, Joseph Ushie

\section{Introduction}

In The Sun Literary Review of Saturday August 4, 2012, Joseph Ushie published an essay entitled "A Neo-colonialist, Linguistic and Stylistic Study of Current African Literature" in which he argues for Neo-colonialism as the most appropriate theory for the interrogation of what he identifies as Current African Literature. His reason for this is premised on the fact that since after "flag independence" (32), African countries, in all spheres of life, namely: political, economic and socio-cultural, have been thriving under the neo-colonial condition. This neo-colonial status of the continent, especially in Nigeria, is seriously inscribed in her post-independent literature(s) or "current literature" as he prefers to identify it. However, Ushie laments that in spite of the apparent neo-colonial condition of the continent, which is manifest in her peoples' consumption pattern, aspirations, power politics and inter group relations, African literature has continually been interrogated through the prism of what he, derogatively, calls "the imposter post-colonial" literary theory (32). To prove this "ignoran[t]" (33) mis-application of reading strategy, Ushie takes us through an expose of the two concepts in contention: Neo-colonialism and Postcolonialism.

Although Ushie has done much to define and give depth to his take on the बatwo theories, it is expedient for a meta-critical endeavour, such as this, to briefly restate his perspective of the theories for the reader's appreciation of the matter hereafter. Leaning on C. L. Innes, Ushie acknowledges that there are two senses of 
the term Post-colonialism - the "hyphenated and the non-hyphenated "postcolonialism/postcolonialism" " (32). The hyphenated is a historical index for the period in a nation's life after it has gained independence and tak en full charge of her political, economic and cultural destiny. However, the non-hyphenated "Postcolonialism" is a cultural concept "within postcolonial studies" that "...is more often used to refer to the consequence of colonialism from the time the area was first colonized" (33). Ushie gives specific examples of post-colonial nations, deriving from socio-economic, technological and political indices as India, Malaysia and America who have demonstrated enough will to successfully extricate themselves from the moorings of their erstwhile colonial masters, and indeed any external control. "Ghana appears to..." be the only country in Africa, by Ushie's logic in that essay, which seems "...poised to turn from her hitherto neo-colonialist status to that of a post-colonial country" (33). Although, we must note at this point, that the exceptional example of Ghana stands to be considered weak due to its obvious lack of factual support by Ushie!

On the contrary, Ushie sees "a neo-colonial society [as] one which was once dominated, but whose economy is still in the predatory grip of foreign interests" (33). To further problematise the neo-colonial condition of such countries, Ushie adds that "such polity also re-introduces internal re-colonization of the weaker elements of the society by the stronger, following independence" (33). Quoting Kwame Nkrumah, to whom the term "Neo-colonialism" is most often associated, Ushie asserts that "the essence of neocolonialism is that the state which is subject to it is, in theory, independent and has all the outward trappings of international sovereignty. In reality its economic system and thus political policy is directed from outside." (33). In summary, Ushie illustrates the basic difference between post-colonial and neocolonial nations with an iconic explication:

a post-colonial country is one which was once colonized but now has only the scars to show for the domination, while a neo-colonial society is one which was once colonized, but which still has reeking wounds to show for the domination even under the leadership of its own people. $(2012,33)$

It is important to note that Ushie also applies the tools of Literary Stylistics to show the depth of neo-colonialism in African Literature with Nigeria as a case in point. This point will become important when we will use the same analytic instrument to aptly characterize Ushie's logic in our own response.

We have attempted to present the core of Ushie's arguments as briefly and faithfully as we can, but it must be stated at this point that his hermeneutics leaves $\infty$ much to be desired. On the whole there is much in his theorizing that is so discomforting and critically awkward. To be unequivocal, this awkwardness lies in ssome half "truths," misrepresentations, conceptual errors and stereotypic $\underset{0}{\infty}$ configuration of the "African" imagination. Although no (African) critic would want to be tagged essentialist, the nuances and attitude of Ushie's theorizing glaringly 
characterize his theory in that mould. It is that extremity that we confront in this paper.

\section{Neo-Colonialist Theorising, Half Truths and some Non Sequitors}

To be fair, we agree with some of Ushie's definitions and elaborations. His distinction between the two types of Post-colonialism is a standard acknowledgement of the nuances of that powerful theory even among postcolonial scholars. However, his definition of the term is simplistic, if one considers the theory's origin, intellectual/philosophical kinship and development as a reading practice in a Postmodern era (another term which, unfortunately, the neo-colonialist may be uncomfortable with). On the other hand, his choice to proceed with his adumbrations on one side of the discursive divide, by declaring that in his study "... we settle for the hyphenated 'post-colonial' because we are discussing specifically what has been happening to a continent after when it was supposed to become free from foreign domination" (33) is even more simplistic and theoretically misleading! The misleading nature of Ushie's discourse is decipherable from his purposeful mis reading and refusal to resolve some matters arising before proceeding with his theorizing.

Once "we settle with the hyphenated "post-colonialism" as Ushie would insist, we are inadvertently blind to some intricate issues in postcolonialism as a cultural theory in the first place and would therefore proceed on a faulty footing. While one would agree that postcolonialism "is more often used to refer to the consequences of colonialism from the time [an] area was first colonized," we must note that colonialism as a cultural phen omenon transcends the politics of countries, nations or states. At the micro level, it is implicated in the individual imagination and even in the politics of inter-personal relationship among sub-cultures within nations. From its early proponents like Frantz Fanon and Edward Said, Postcolonialism has become more of an endogenous cultural reading strategy that interrogates how individuals appropriate systems of thoughts and signs to assert their personality not necessarily to live the life of another superi or force or to subsist in the hegemony of a subject. Postcolonialism has become descriptive of a disposition to rise from the suffocation, even, of one's kind not necessarily from foreign political, economic and technological power. Giving us a general definition of Postcolonialism, Homi Bhabha says "Postcolonial criticism bears witness to the unequal and uneven forces of cultural representations involved in the contest for political and social authority within the modern world order" (245). He goes further to state that postcolonial perspectives

..intervene in those ideological discourses of modernity that attempt to give a hegemonic 'normality' to the uneven development and the differential, often disadvantaged, histories of nations, races, communities, peoples. They formulate their critical revisions around issues of cultural difference, social authority, and political discrimination in order to reveal the antagonistic and 
ambivalent moments within the 'rationalizations' of modernity. (USHIE 2012, 246)

As C. L. Innes, who Ushie relies on for his major definition, tells us, Spivak has utilised the concept of the subaltern to analyse the situation of women under patriarchal codes (11). In fact, women's literature in Africa helps us to understand the peculiar slant to Postcolonialism articulated by Bhabha and Spivak, but which unfortunately still defies some people's comprehension. The silenced, depersonalized woman in the attic of Charlot Bronte's Jane Eyre did not have to be of a colonized race or from a Third World before being suppressed by a chauvinistic English elite character of the $19^{\text {th }}$ century. In the Diaspora, the works of Toni Morrison, Alice Walker and Terry Macmillan articulate very clearly that we have to be aware of another form of colonialism beyond country or nationality. Of course, these African American women writers were continuing a counter-hegemonic narrative that their rhetorical/creative fore-mothers such as Sojourner Truth, Harriet Jacobs, Zora Neal Hurston, among many others, had established years before them. It is in this context that Postcolonialism accounts for more subtle but palpable forms of colonialism than Ushie would reveal to his readers.

\section{The Subtleness of Postcolonialism in "Current African Literature"}

We shall soon come to why Ushie, probably, ignores these levels of oppression and the resistance of the characters implicated in them as victims. But let us first illustrate how this dimension of postcolonialism that we are advancing works in current African Literature. In Africa also, women writers especially have been instrumental in redefining colonialism. From Flora Nwapa and Nawal el Saadawe to Tsitsi Dangarembga and Chimamanda Ngozi Adichie, the postcolonial perspective equips us to uncouple another sinister form of subjugation beyond Western national colonialism. In Nervous Conditions, Dangarembga negotiates the delicate tension and mental kinship that are implicit in Western colonialism and gendered subjugation. The young radicalized female character, Nyasha, in Nervous Conditions, who feels dominated and brutalized by her father (a patriarch of a large Zimbabwean family) articulates this tension in a very apt but schizophrenic manner. In a moment of crisis, after a faceoff with her father she indexes the subtle dimensions of oppression within which she and other characters, even her father thrive

They've done it to me... . They did it to them too... . They've deprived you of you, him of him, ourselves of each other. We're grovelling. Lucia for a job, Jeremiah for money. Daddy grovels to them. We grovel to him.... (DANGAREMBGA 1988, 200)

NFrom the above introspection, we would see that at the height of her schizophrenia, coNyasha specifies the subtleness of the Western colonial project, "their history. ... $\sim$ [and] [t] heir bloody lies" (201) that have made her, like every other African, a split personality: "I'm not one of them but I'm not one of you" (201). 
The masculinist logic which rules Zimbabwean traditional and contemporary society is very palpable in that novel but even more tangible is the fact that the women in Nervous Conditions seem to band or to use a feminist jargon bond together as subordinates to the male principle in their culture. We find an interesting inter-textual conversation, in this regard, between Dangarembga and the Nigerian novelist Adichie. Beyond the feminist thematic in Dangarembga's Nervous Conditions and Adichie's Purple Hibiscus, there is an instructive dimension to gender in the novels, which challenges the simplistic application of neo-colonialism to all "current African Literatures." The father-figures in both novels represent another tensioned site. Dangarembga's domineering father, Baba Mukuru and Adichie's "Papa" (Mr. Eugene) are both curious postcolonial types. Both men index the crisis of masculinity in postcolonial cultures. Here we have two male characters from two different parts of Africa who are struggling hard to negotiate the gender responsibilities expected of them by “... deep and clashing cultures" as Dennis Chukude Osadebay (15), one of Africa's pioneer poets would have it.

Thus for Dangarembga's Baba Mukuru, to be a real man, he has to maintain a large compound of women and children, some of whom are not of his nuclear family. On him lies the responsibility to custody and perpetuate a patriarchal ethos in a modern Zimbabwean society, even as member of the middle class. Like Baba Mukuru, Adichie's Mr Eugene is burdened by two cultural codes (Western and Igbo) to which he feels heavily indebted. His own strategies of mediating the tensions between Western civilization and his Igbo ethos become very fatal. As a thorough-bred Catholic, groomed by strict doctrines, Mr Eugene stretches his Christian piety and devotion to God to the limits. Thus, he would superintend $h$ is children's sacrament of reconciliation and their entire worship in church; he burns his daughter's, Kambili's feet with hot water from a kettle to teach her a lesson on avoiding sin - "that is what you do to yourself when you walk into sin. You burn your feet" (194). Yet Mr. Eugene is seen as a benevolent man, a benefactor to his Umunna (his extended family), and in fact, his entire village. He maintains a big house and gives handouts to the needy around him.

In spite of all the vicious things that Mr. Eugene does to his family, it would be misleading to see him in the frame of a villain. His character delineation calls for a more critical empathy. His types are the distorted African progenies made so by the pressures of Western colonialism and the expectations of indigenous traditions. This, to us, is the point that Adichie is making in that novel. Although this is not the space to give the psychoanalytic dimension to such interesting breed of postcolonial characters, it would do us well to notice that Mr Eugene, in Adichie's Purple Hibiscus, is always helpless whenever his Unconscious takes over him. As he burns his daughter's feet the child narrator, who is the victim herself, tells us that J“" h]is voice quavered now, like someone speaking at [a] funeral, choked with comotions" (194). All through the novel Adichie portrays a male character that is $\approx$ pitiable and striving to come to terms with his own mental crisis. For strange reasons, he would beat his wife even into miscarriage; he suspects his son's quiet moments as 
times for masturbation and insists that he (his son Jaja) confesses the sin at the confessional.

In view of the foregoing, it would be uncritical for one to exclude other reading strategies to the text. Rather, we would say that postcolonialism affords readers the most appropriate critical and inter-textual grammar with which to understand the core of texts such as Nervous Conditions and Purple Hibiscus. As good as neo-colonialism is, on its own, it cannot account for the dynamics of power politics, cultural tensions, psychosis and their implication on gender and the strategies of survival by different characters as "colonial" others in the above texts. The tensioned masculinity which is the issue in the above "current African" texts cannot be properly excised by neo-colonialism as defined by Ushie. This is because masculinity, at least, in Africa, is a consequence of both indigenous and foreign cultural expectations. These expectations are definitely not only economic or even solely political.

\section{Testing the Logic of Neo-colonialist Theorizing in Nigerian Literature}

This then brings us to another inconsistency in Ushie's advancement of neocolonialism as a literary theory. His materialist reading of the African imagination, especially in the superlative terms that he articulates it, is a fundamental error-injudgment. One suspects an obsessed Marxist impetus to this materialist posture, and the point must be made that there is nothing wrong if Ushie is fed by a Marxist impulse. But an obsession with a particular ideology blinds one from alternative discourses that literatures like "current African Literature" really need. If we may apply the instrument of stylistics which Ushie ably utilizes in interrogating the depth of the consequences of neo-colonialism on the literature of his generation of poets, one would appreciate better the fountain of his own mis-judgment and misapplication of neo-colonialism. In literary theorizing and indeed in any postulation in the humanities, we must be cautious not to speak in extremities and finalities; not even in the exact sciences is that done. In fact, in the latter we often hear of "plus $(+)$ or minus (-) this and that," which gives allowance for other variables. In fact, when the economists say "everything being equal," it is said in the consciousness that everything may never be equal! But in his advocacy of neo-colonialism, Ushie sees the African imagination as deriving solely from political/economic variables as if to say this is all that determines human existence and human imagination there from. It is the totalising code with which he concludes on creativity on the continent that discomforts one a bit.

In his prognosis, the word "essentially" recurs not less than six (6) times as a qualifier for African Literature(s), African literary arts/artist and African society. NWith it is another modifier - "material" - which appears with its collocate “"condition" (material condition) appearing not less than eight (8) times in describing coAfrican society, which, for instance, "has remained essentially a neo-colonialist - rather than a post-colonial continent..." (32), because of the material conditions of the continent (emphasis added, 34). Or in describing African literature which is neo - 
colonial deriving from "...the material realities of most 'independent' African countries" (emphasis added, 32). Where the word "essentially" is not used in typifying Africa or its literature/artist, it is varied in that essay with "most" (33), "truly" $(32,33)$, "generally" $(32,33)$, "especially" (34), or "typical[ly]" (33). To my mind these words are not mere modifiers/qualifiers. They function grammatically as intensifiers of an ideological position. But this position is nothing but a stasis. For it configures African literature(s) as a product of not just a fixated society but of a static imagination. It is therefore easy for us to see all African literatures, even those that recreate the environment from the neo-colonialist prism - "Neo-colonial Ecocritism" (35). After all, the entire continent is essentially neo-colonialist and most of her literatures are truly typical reflections of the African material condition generally. Once we accept and imbibe this Ushiean paradigm we probably have finally arrived at the "magic fountain" (WA THIONG'O, 2000) of the criticism of Current African Literature because, perhaps, neo-colonialism from this paradigm becomes society-specific or "particular-society-sensitive" (33) and by extension indigenous. But we know that the complex that gave birth to Ben Okri's The Famished Road or even the entire poetry of Ushie's own generation of poets is not simply neo-colonialist.

The "Abiku" child of Okri's The Famished Road is a true creation of a postcolonial world and a postcolonial imagination. That spirit child utilizes the powers of an African 'magic' world to transcend the boundaries of his local space into becoming a transnational being even as he still carries with him his local "Abiku" nature. With its roots in the Derridan conception of signs, which is in turn empowered by the multi-valence of postructuralism, the postcolonial perspective equips us with the insights to appreciate the consilience of African cosmology and the tensions of contemporary experiences that have bequeathed us the "Abiku" character. That character is not just a phantasmagoria but a metaphor of the hybridity that has become the identity of Africans, and if one may generalize, the identity of other postcolonial peoples - Malaysians, Indians, Pakistanis, American Indian etc.

On the other hand, we would be missing the point if we conclude that the poetry of the third generation of modern Nigerian poets, Ushie's own generation, is "essentially" a product of the neo-colonial condition and should be analysed mainly from that perspective. We may want to consider some facts about poetic beginnings before we run into the Ushiean fallacy. Here again, we should not be shy about using foreign models to interpret phenomenon in our cultural industry. Consider that "foreign" medicine like indigenous medicines have helped in diagnosing and curing African diseases and you will not be scared of being labelled "imposter." The context within which this third "generation" of modern Nigerian poets under discussion Memerged is not just socio-politically and economically hostile. It is also artistically Whegemonic. Many critics pay witness to the fact that given the brain drain of the early 0080s through the 90s and the subsequent flight of quality cultural scholarship abroad $\widetilde{\tau}_{\text {this }}$ generation of poets were bequeathed a heritage of lack and dispossession, the depth of which Ushie captures in his present essay under discussion. 
Given this generally poor intellectual/educational background, this generation of poets was not expected to produce any art of quality and thus, to further the horizon of Nigerian poetry. This situation prepared the ground for a psychoaesthetic battle of survival which Harold Bloom's theory of poetic beginning - "The Anxiety of Influence" - can only help us explain and understand. The intellectual exchange between this young embattled generation and their immediate poetic precursors - the Ofeimuns, Ojaides and Osundares - relieved rich critical insights to the development of Nigerian poetry up to date. In fact, Inyabri (2012) has deve loped a theory which sees Humour as a defining quality of this generation's poetry and indeed an existential strategy which has bequeathed us some of the most beautiful poetry of our time. Ogaga Ifowodo, "one of the shining stars" (ADESANMI 2002, 124) of this generation seems to write the poetic manifesto of his time when his persona says: "For art sake/ we shall shun pain/ and write lyrics of the ear. .../ We shall roam the full earth/ and see no pain on our paths/ and see no pain on our paths" (11).This motif is prevalent in the best of poetries in this generation. We have it in Remi Raji's "Black Laugther" (19-20) where the poet persona also dares to laugh in the face of pain:

even though I grope

in the morning mist of harmattan

and blind lanterns lead my weary legs

limpid vehicle of visible fate

Wide and deep, wide and deep

I will laugh; beyond the chills

beyond the thrills and threats

of conditioning yoke

Wide and deep I will laugh. (19)

We also have this quality of poetry, observed in Ifowodo and Raji, running through Rotimi Fasan's poetry especially in "Caravan of life" (59-60) where the "Conductout" (60) provides us the humour with which to confront the collective tragedy of city life in post-independent Nigeria. In fact, Fasan's "conductout" is a poetic kin of the late Adolphous II Amasiatu's city scum, the area boy in "The Fiery ¿مEyed Hawk" (29). 
From the foregoing, it would be observed that the impulse which fired this generation of poets in the first place cannot simply be explained off by neocolonialism. It runs deeper than that. In fact, it goes beyond the paradigm of that simplistic explication. The general pain, dispossession and desperation characteristic of the environment against which this generation of poets wrote cannot also be justified by the neo-colonial model. Perhaps we should pause to ask ourselves when African scholars would restrain from seeing our problems as deriving predominantly from external machinations. One is not positing that neo-colonialism does not exist or could not be used to interrogate African conditions completely. But as critics of cultural factors, we have to be cautious else solutions elude us and the understanding of our own angst gets lost in a diversionary chase.

It is stunning that half a century after Nkrumah we still insist on a model that is externally fixated to decipher our predicament. We know that some Africans would insist on a remote Euro-American hand in all the coups and counter coups in Africa. But since after the cold war, with what level of propr iety can we blame the ethnic/tribal wars and electioneering crisis in East Africa to neo-colonialism? Can we simply explain the monumental plunder of the oil wind fall of the '90s in Nigeria, a largess of the gulf war, to neo-colonialism? Perhaps the blight of the system and the state terrorism that defined the Abacha dictatorship is also a neo-colonialist machination! To our mind the poetry that arose in the mid-80s did not do so by looking outward. It was looking, squarely, at vicious principalities at ho me apart from coming to terms with some internal private longings. Critics of this poetry would do well to adopt theories that would analyse that poetry in its aesthetic complexities rather than going in search of "particular society-sensitive" (USHIE 2012,33) models that would not address the merit of the text.

In fact, any theory which helps to bring out the essence of a text is valid as far as it answers basic questions relevant to the text and its society. What is important is discovering what Pius Adesanmi would refer to as "the un-mistakable African genius" (131) in any current African text. That genius can be discovered and appreciated through any appropriate model. Perhaps, some other study needs to elaborate for us what the third generation of Nigerian writers, especially poets, has gained for this country in the publishing industry. One wonders how the neocolonialist model would explain the fact that a literature which emerged and thrived essentially in a neo-colonial condition has evolved a robust home grown publishing industry which in turn has given voice to a new generation of writers who held the fort through the perilous reign of dictatorship in Nigeria and brain drain. We do not have to look far for the gains of that period: Kraft books, Bo ok Kraft, Oracle Books, Malthouse and many other publishing houses remain monumental testimonies to the $\checkmark$ postcolonial forces that gave birth to them.

However, it must be observed that Ushie's form of cultural materialism is @onot new in African literary discourse. Ngugi Wa Thiong'o had even articulated it better in many ways and keeps going back to the issue through several guises in his theorizing. In fact, Ushie's essentialism with regards to neo-colonialism, reminds us 
of wa Thiong'o's own humanist, reductionist delineation of the locus of "literature and politics" as far back as the 70s. As he (wa Thiong'o) would have it, “... literature and politics are about living humans, that is to say, actual men and women and children, breathing, eating, crying, laughing, creating, dying, growing, struggling, organizing, people in history of which they are its products, its producers and its analysts" (WA THIONG'O 1981, 68, emphasis added).

With some sense of intellectual humility we think that wa Thiong'o's about-ness of literature and politics in the context of the emergence of environmental studies, Literature and the Environment, Ecocriticism, etc., is fundamentally challenged. But without belabouring the point it would suffice to mention the example of wa Thiong'o's argument in his "Europhonism, Universities and the Magic Fountain: The Future of African Literature and Scholarship" (1). In that essay, an Ashby Lecture given at Clare Hall, Cambridge, in May 1999, wa Thiong'o asserts that all African literatures written in European languages are serving the grand plan of the Horton-Asquith Euro-colonialist plan of culturally defacing Africa through education, articulated and inculcated primarily, in European languages. Of course we know that wa Thiongo's theories and creative writings always build up on his ageold Marxist/Hegelian dialectics, in which as Adesanmi would have it, wa Thiong'o “... persistently attempts at inducing a feeling of guilt in African writers and scholars who continue to work in European languages ...” (109). In our case, Ushie wishes to induce the same guilt of neo-colonialism in all African scholars/critic who use "foreign" theoretical models in the explication of the African text. But as we had observed of Ushie's rhetoric above, Adesanmi re-enforces our opinion when he states that: "the picture that one gets from Ngugi's essay is that of a static, unchanging institution (in our case a nation), fossilized as it were in an uncritical legitimation of the imperialist ideologies that gave birth to it" (111).

It is interesting to note that fifty years after Nkrumah talked of neocolonialism the frontier of African literary arts has fundamentally changed. Perhaps, given his aversion for foreign imposter theories, Ushie would not agree that other forms of African literary textualities have emerged, even in popular music. The unfortunate division between "popular" and "serious" art has gone a long way to further circumscribe and hegemonise various types of youth artistry which articulate some of the most outstanding impulses of our time. Here also we encounter a subtle form of "colonialism" which the youth as artistes engage and subvert in order to articulate their subjectivity. Through the Postcolonial per spective, popular Nigerian music could be seen as art forms that weave African orality and transnational afro diasporic art motifs to produce a mosaic of postcolonial/postmodern art. This art breaks through all conservative nativist boundaries to assert it self. It is because of its postmodern, "transnational" and "translational" (BHABHA 1994, 303) character that contemporary Nigerian pop music is thriving. Nigerian video, which Ushie Eacknowledges as a thriving art form shares the same cultural industry with popular

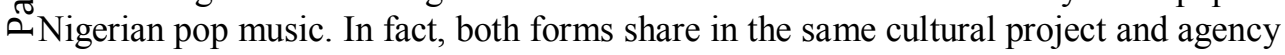
as have been argued somewhere else (INYABRI 2013). 
Hence, if we are looking out for what Nigerians would export to the world - in order to free them from the jinx of neo-colonialism as Ushie would suggest these popular forms are already doing that and offer us much more possibilities. Indeed, Nigerian popular music and videos are breaking through international boundaries and seriously engaging music critics and event managers in Europe and North America. It is beyond this study to quantify the commercial potentials of these art forms, but one knows that herein lies a genre that holds tremendous promise for our GDP. While the GDP may not be our primary concern he re, suffice it to say that the Postcolonial perspective enriches our insight into popular art forms across the continent. With the Postcolonial perspective these art forms are interrogated for what they are and not what they are not. Instead of stereotyping them with some societyspecific models, the Postcolonial perspective releases them from further hegemonies and moves them from the fringe to serious scholarly inquiry.

Reading Ushie's advocacy for Neo-colonialism, one has the feeling that African critics have not done much, if anything, to evolve Africa-centred literary theories. The issue of that "guilt inducing" tendency in his adumbration comes more to the fore again. But if literary theories "...offer us various ways of defining literature..." or if it "... provides us with a range of criteria for identifying literature in the first place [and]... make us aware of the methods and procedure which we employ in the practice of literary criticism..." (WEBSTER, 5, 8), African critics and literary scholars have been developing different society-specific theories in dealing with African literatures. From the first generation of modern Nigerian writers to Ushie's own generation, we have continued to witness these different attempts at systematizing literary hermeneutics in Africa. Nigerian literary scholars have been at the fore of this engagement in Africa. We shall take note of few examples in order to help us appreciate the issue. Wole Soyinka, for instance, theorizes myth as the centre of the African imagination in his "Myth, Literature and the African Imagination," Chinua Achebe configures the literary writer as teacher in his response to colonial narratives and the responsibility of the African writer to his people. In the 70s, the great debates over African drama relived interesting postulations about the nature and status of traditional and modern African drama. Worthy of mention here is Ossie Enekwe's location of mimesis as the validation of traditional African performances as drama in his "Myth, Ritual and Drama in Igbo-land" (149). It is instructive to note that Enekwe's theory and others like his have conditioned and defined our reception and teaching of modern African Drama in African schools and colleges to date.

Furthermore, in his reading of the trajectory of Nigerian poetry, Funso Aiyejina theorizes the public slant in Nigerian poetry in what he topically calls "The Alter/native Tradition." Recently, he (Aiyejina) has also applied the sa me exquisite

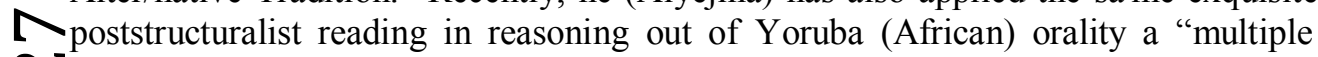
Noptions" (10) revolutionary approach to the reading of African and African diasporic coliteratures. Esu, that catalytic mythic character - "...the mythic ancestor of Che

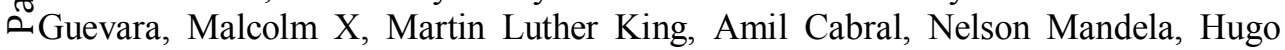
Chavez, Wole Soyinka, Adaka Boro, Ken Saro-Wiwa, Gani Fawehinmi, Femi 
Falana, Fela Anikolapo-Kuti, etc." (6-7) remains the hermeneutic site of this theorising. We can go on to mention D. S. Izevbaye's revisionism which states that "...the beginning of a new literature is linked with the end of an existing culture: one makes the other possible" (70). Izevbaye's theory is encapsulated in a very iconic title "The Fired Image: Literary Beginnings from Cultural Ends" (69). In feminist literary theorising, Mary Modupe Kolawole's "womanism" galvanises indigenous African and African diasporic feminist values to validate feminism in Africa. Before her, Molara Ogundipe-Leslie came up with "stiwanism,", a theory which engages gender hegemony within the peculiar socio-cultural/political circumstance of Africa.

We have particularly mentioned theoretical activities in Nigerian Literature but it must be noted that they sign-post sundry theoretical perspectives all over Africa. However, none of these theories, perhaps except Ushie's neo-colonialism and Ngugi's Hegelian/Marxist theorizing, seems to be so exclusionary and extreme in tone. But the irony of looking for more society-specific paradigms is that we end up with the precedence. In his attempt at suggesting alternative/indigenous names to the Nigerian movie industry - so that it frees itself from the moorings of Western, neocolonial hegemony - Ushie is himself intriguingly strapped to Western models and thought patterns. Thus, for Hollywood, he proposes "Enugu Hills, Obudu Hills, Yankari Reserves, etc." (34). One wonders if we are not back to the beginning. If we are to decolonize our minds or de-neo-colonize our condition (perhaps as Ushie would prefer), must we even think of our movie industry in terms of landscapes? Are we not trapped in the ideational/ideological topographies of Western models? The point here is that (literary) theories should be seen, in many regards, as dialogues, conversations or rhetorical exchanges which offer perspectives to texts/discourses. This is the robust way in which African literature should be engaged. This is the perspective that current African literature in the $21^{\text {st }}$ century needs!

\section{Conclusion}

Ours has been, primarily, a cautionary response to what seems to be a fixated view of a theory and its approach to current African literature. We have reacted specifically to Ushie's proposal of neo-colonialism as the most appropriate theory for the interpretation of current African literatures. Our effort has been to address the extremity of his opinion, the inconsistencies in his paradigm and the exclusionism that is implicit in his proposal. To our mind, Ushie proceeds from a perspective that is not only faulty but, perhaps, also purposefully ignores fundamental intricacies of the impulses which gave rise to and have continually fed the dynamics of postcolonialism as a cultural theory. This is in spite of the acknowledgements of such intricacies by canonical critics of the theory who Ushie himself makes references to. OFor instance, C. L. Innes advises his reader that "it is important to be aware of the $\mathrm{N}_{\text {development of postcolonial studies and the peculiarities of the discipline, in order }}$ conot to be confined by its present boundaries and terms, but to question and modify ¿them" (emphasis added, 3). Ushie's theorizing has completely ignored this caution. 
He does not display or, should we say, he denies his reader an awareness of "the development" and "the peculiarities" of a theory he chooses to tag [an] "imposter."

We have already noted Ushie's tendency to think of postcolonialism as a foreign theory and implicit in his opinion also is the tendency to see the theory as not being radical enough to engage what he thinks is the neo-colonial condition of African societies. This of course will be the conclusion if we ignore the rise and development of the postcolonial theory. But Robert Young whose [Postcolonialism: An Introduction] remains one of the most authoritative insights to the theory informs us that:

postcolonial critique incorporates the legacy of the syncretic traditions of Marxisms that developed outside the west in the course of anti-colonial struggles, and subsequently in the development of the further forms of emancipation, of gender, ethnicity and class, necessary for the liberation from bourgeois nationalism. $(2001,10)$

Furthermore, Ushie ignores the dynamic definition of colonialism which has evolved with the Postcolonial perspective and which we have attempted to make obvious in this paper. More so, Ushie has not made his reader to understand the subtle and complex nature of Postcolonialism which enables it to cater for the same ideological issues that neo-colonialism partially engages. Again, Young accounts for this complexity when he states that "[P]ostcolonial critique focuses on forces of oppression and coercive domination that operate in the contemporary world: the politics of anti-colonialism and neo-colonialism, race, gender, nationalisms, class and ethnicities define its terrain" (11). It seems to us, therefore, that Ushie's theorizing is tantamount to treating symptoms rather than the sickness, prescribing a single drug rather than a broad spectrum therapy for "social pathologies" (BHABHA 1994, 246) in Africa. It becomes easy therefore, to suggest that internal colonialism or what he calls "internal re-colonization" (33) is a feature of neo-colonialism without noting the problematic of internal colonialism as a theoretical model on its own. But we know that the problematic of internal colonialism is not as simplistic as Ushie has laboured to present it.

In fact, "domestic colonialism" (73) as Ken Saro-Wiwa would refer to it has also been traced to tendencies outside neo-colonialism. Michael Hechter who applies the theory of internal colonialism to the interrogation of the Celtic condition under British hegemony did not see the concept as a subset of neo-colonial. Rather Hechter interprets internal colonialism in the socio-political and cultural terms of core/periphery discourses which are the main fort of Postcolonialism. Thus, while we agree with Ushie that internal colonialism could thrive in neo-colonial spaces, it should also be understood that there are contexts in which internal colonialism thrives outside neo-colonialism. In any case, internal colonialism or "internal reतcolonialism," to use Ushie's term, is traceable to Lenin, Gramci and Fanon (HECHTER 1975, xvii \& 9). If we are to test its indigenousness or specific-ness, we should be reminded of its origin. The point one makes here is that we should be 
cautious of the tags we give to theoretical models in the study of African literary texts.

It must have been noticed that in some contexts we use the plural case to refer to African literature(s). This of course is in keeping with the overall scepticism of our postmodern condition and the subtle nuances that mark literary creations in the continent. We acknowledge the basics that unite African textualities but we must also know that there is a limit to thinking of creativity in a holistic model lest we fall into the same fallacies we are addressing.

Finally, while we differ with Ushie in many ways, we must emphasize that the value of his proposition is that it sets us rethinking the bases upon which we are to comprehend African literature(s) in the Twenty-First Century. More so, his hermeneutics brings to the fore what Bhabha has topically called "the commitment to theory" (28) which will help us to understand the institution of literature itse lf and "...the tensions within critical theory... and its revisionary forces" (BHABHA 1994, 47). The African student of literature needs this understanding and a reasoned engagement with it. As it is today, many of us and our students display a frightening lack of this knowledge that is a key currency in global intellectual/cultural politics.

\section{Relevant Literature}

1. ADESANMI, Pius. "Europhonism, Universities and Other Stories: How not to speak for the Future of African literature," [Palavers of African Literature: Essays in Honor of Bernth Lindfors, TOYIN Falola and BARBARA Harlow Eds.), pp105-36, 2002. Vol 1., AWP: Trenton, NJ. Paperback

2. ADICHIE, Ngozi Chimamanda. [Purple Hibiscus], 2003. Farafina: Lagos. Paperback.

3. AMASIATU, Adolphus II. [Swords and Roses], 1996. Mace Associate: Lagos, Paperback.

4. AYEJINA, Funso. "Esu Elegbara: A source of an Alter/Native Theory of African Literature and Criticism," [CBAAC Occasional Monograph], 15, 2010. Paperback.

5. AYEJINA, Funso. "Recent Nigerian Poetry in English: An Alter/Native Tradition", [Perspectives on Nigerian Litera ture, 1700 to the present], Vol I. pp112-28, 1988. Guardian Books: Lagos. Paperback. 
Filosofia Theoretica: Journal of African Philosophy, Culture and Religions

6. BHABHA, Homi. [The Location of Culture], 1994. London: Routledge. Paperback.

7. BLOOM, Harold. [The Anxiety of Influence: a theory of Poetry], 1973. OUP: London. Paperback.

8. BRONTE, Charlotte. [Jane Eyre], 1992. Wordsworth: Hartfordshire. Paperback.

9. DANGAREMBGA, Tsitsi. [Nervous Conditions], 1988. Seal Press: Washington. Paperback.

10. FASAN, Rotimi. [Evening of My Doubts], 2001. African Cultural Initiative: Lagos. Paperback.

11. HECHTER, Michael. [Internal Colonialism: the Celtic Fringe in British National Development], 1975. Transaction Publishers: London. Paperback.

12. INNES, C. L. [The Cambridge Introduction to Postcolonial Literatures in English], 2007. C.U.P: New York. Paperback.

13. INYABRI Idom T. "Youth and Postcolonial Subjectivity in Contemporary Nigerian Pop Music," [Postcolonial Text], pp1-17, 2013. Vol 8. No 3 \& 4. Web.

14. _. "Humour as an Aesthetico Existential Strategy in Third Generation Modern Nigerian Poetry," [Global Journal of Social Sciences], pp99-105, 2012. Vol 11. No 2. Paperback.

15. OGAGA, Ifowodo. [Homeland and other Poems], 1998. Kraft Books: Ibadan. Paperback.

16. OSADEBAY, Dennis Chukude. "Young Africa's Plea," [West African Verse: An Anthology, DONATUS I Nwoga Ed.], p17, 1967. Longman: Harlow/Essex. Paperback.

17. RAJI, Remi. [A Harvest of Laughters], 1997. Kraft Book: Ibadan. Paperback.

18. SARO-WIWA, Ken. [A Month and a Day: A Detention Diary], 1995. Spectrum: Ibadan. Paperback. 
19. USHIE, Joseph. "A Neo-colonialist, Linguistic and Stylistic Study of Current African Literature," [Saturday Sun], pp32-36, August 4, 2012. Vol 9. No 501. The Sun Publishing: Lagos. Newsprint.

20. WA THIONG'O, Ngugi. [Writers in Politics: A Re-engagement with Issues of Literature and Society], 1981. James Currey/Heinemann: Oxford/Nairobi. Paperback.

21. _. "Europhonism, Universities, and the Magic Fountain: the Future of African Literature and Scholarship," [RAL], Pp1-11, Spring, 2000. Vol 31. No 1. Paperback.

22. WEBSTER, Roger. [Studying Literary Theory: An Introduction], 1990. Arnold: London. Paperback.

23. YOUNG, J.C. Robert. [Postcolonialism: An Historical Introduction], 2001. O.U.P. Paperback. 